\title{
TECHNOLOGIES, TEACHING OF LAW AND A COMMUNICATIVE THEORY OF LAW
}

\author{
Fernando Galindo
}

\begin{abstract}
The article is structured as follows: It initially considers the change in the orientation of the teaching of jurists, exemplified by the demands of the Bologna process; examines, in a Second section, the limitations of the discussions on Legal Informatics that have taken place in the last thirty years; the next Section discusses the possibilities of undertaking a critical position on a dogmatic juridical approach whose content is exclusively focused on the study of legal texts; the last Section argues that a wide-ranging framework of reflection, debate and support for social needs and competences can result in a communicative theory of Law.
\end{abstract}

\section{Table of contents}

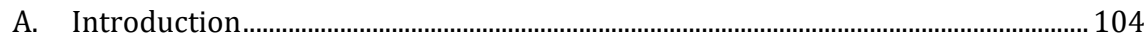

B. Skills and Competences Required to Practicle Law ................................................. 105

C. The Limitations of the Discussion on «Legal Informatics» ...................................... 109

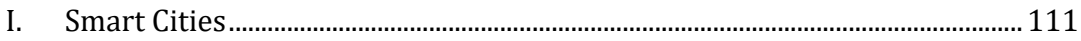

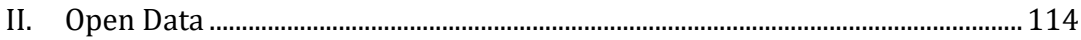

D. A Judicial Reflection Critical of Dogma.................................................................. 115

E. The Current Framework of Reflection and Debate ................................................. 123

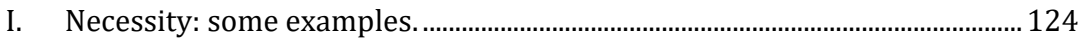

II. The Communicational Theory of Law................................................................ 127

III. Limitations of Communicational Theory ........................................................... 129

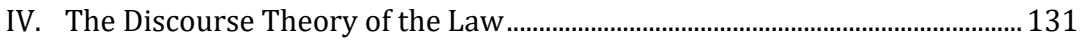

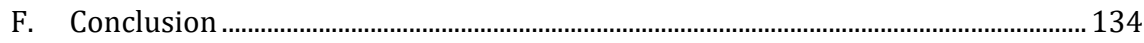




\section{A. INTRODUCTION}

The theoretical justification of the use of technology in the legal profession is not a simple matter. Despite the fact that discussions on defining a framework for computer science and the legal arena (Legal Informatics) are well-established, their conclusions have not met with general agreement and acceptance. The limitations of this debate are shared by all legal discussions on any theory, that do not have, as the sole objective, legal texts or norms approved by the powers authorised to develop and implement them.

A change in perspective became necessary due to the unquestionable social and political relevance of the use of new technologies in the context of administrative and judicial authority in the resolution of conflicts through legal proceedings. The significance of this relevance can be seen in the modification of the terms used in the exercising of administrative and judicial power, with expressions such as «e-Government» ${ }^{1}$ and «e-Justice»².

The need for a new perspective is even more pressing when, as we have seen in the area of continental Law, measures are approved that change both the basic education and continuous training of legal professionals. This is happening in Europe with the progressive implementation of the «Bologna Process» which establishes that the planning, execution and evaluation of higher education training must be based on satisfying social requirements and specific professional competences that are not necessarily founded on theoretical arguments and debates ${ }^{3}$.

This text is structured as follows: Section B considers the change in the orientation of the teaching of jurists in Spain, exemplified by the demands of the Bologna process; Section $C$ examines the limitations of the discussions on Legal Informatics that have taken place in the last thirty years; Section D discusses the possibilities of undertaking

1 On implications, see, for example: OCDE, E-Gobierno para un mejor Gobierno, 2008, Madrid, 230 pages.

2 FUNDACION TELEFONICA, Las TIC en la Justicia del futuro, 2009, Barcelona, 361 pages.

3 On the reforms in general and the study plans for lawyers and doctors, see: EsCANERo, F., Galindo, F., Guerra, M., LaSAla, P., Soria, M.S., Estudio sobre el aprendizaje. A partir de varias experiencias realizadas en Facultades de Medicina y Derecho, 2017, Zaragoza, 356 pages. 
a critical position on a dogmatic juridical approach whose content is exclusively focused on the study of legal texts; Section E argues that that a wide-ranging framework of reflection, debate and support for social needs and competences can result in a communicative theory of Law; and, the final section F briefly outlines the Conclusions of the work.

\section{B. SKILLS AND COMPETENCES REQUIRED TO PRACTICLE LAW}

At the same time as the implementation of the reforms promoted by European Higher Education Area, the last years have seen changes in the training of lawyers and solicitors in Spain as a response to social and professional demands. These changes were expressed by Spanish Law 34/2006, of the $30^{\text {th }}$ of October on access to the professions of lawyers and solicitors 4 . It is worth focusing on these changes as they exemplify reforms that require a balance between needs, behaviours, concepts and theories in legal training.

The Law was particularly significant as it established the requisite of passing a national state examination in order to be able to practice law; the previous requirement was admittance by the Professional Associations and to hold a degree in Law - the proof of a basic knowledge of jurisprudence and concepts developed by the dogma or science of the Law.

Therefore, it became necessary to modify the study of Law, for both undergraduate and postgraduate degrees, in order to equip the future jurists with a series of professional skills and competences to satisfactorily exercise legal activities.

The skills and competences set out in the new regulation are tailored to the current cultural, social, economic and geographical conditions in which lawyers and solicitors practice their profession. In accordance with the Rule of Law, the skills and competences are established in the Laws that generically determine the procedures for the promulgation and application of the Law, as well as the characteristics of the activities of the jurist (ethical rules).

4 https://www.boe.es/buscar/act.php?id=BOE-A-2006-18870. 
Article 1.1 of Law 34/2006 on access to the professions of law defines a lawyer as a collaborator «...in exercising the universal right to effective judicial tutelage, with the aim of guaranteeing the citizen access to legal guidance, defence and representation of quality». A more specific reference to professional activities is given in article 1.2: «For $o b$ taining the professional title of lawyer in the manner determined by this law, it is necessary to provide legal assistance for judicial and extrajudicial processes in which current legislation requires or empowers the intervention of a lawyer, and, in any case, to offer legal assistance or advice using the denomination of «lawyer»; all of this without prejudice to the compliance of any other requisites demanded by current regulations on practising law».

The required professional qualifications are specified in Royal Decree 775/2011, of the $3^{\text {rd }}$ of June, which established detailed arrangements for the implementation of Law $34 / 2006^{5}$. The decree regulates the education and training of lawyers and solicitors before and after gaining a Law degree or Masters, through participation in courses imparted by university professors and lawyers, as well as a period of professional work experience in an institution or organisation involved in judicial activities.

As can be seen below, the series of competences established by the Royal Decree of 2011 for both undergraduate and postgraduate studies are concerned with: the idea that the dogmatic legal theories explain, present or express the judicial reality in the form of professional activities (a); that life, professional legal activity or the results of social studies (competences b-e) are the objectives of the theoretical principles which refer to them (this question will be further discussed in sections $C$ and D of the present work).

The aforementioned laws and regulations give five main areas of competences and skills necessary for those wishing to enter the legal profession:

a) Judicial Activities.

- Knowledge and understanding of abstract concepts of legal dogma or the science of the law, national and international legal systems and regulations and the different areas of professional practice.

5 https://www.boe.es/diario_boe/txt.php?id=BOE-A-2011-10459. 
- The ability to interpret the Law, in accordance with the regulations of judicial practice and the characterisation of problems.

- The ability to apply judicial and extrajudicial Law.

This first set of competences illustrates how the academic curriculum of the Law degree and, to a lesser extent, the postgraduate Masters, continues to focus on subjects that the science of law or legal dogma has been developing since Legal Codes were established at the end of the $18^{\text {th }}$ and throughout the $19^{\text {th }}$ centuries. This is particularly the case with the requisite that jurists must have »...knowledge and understanding of abstract concepts of legal dogma or the science of the law, national and international legal systems and regulations and the different areas of professional practice». ${ }^{6}$

The remaining skills and competences are clearly different from the aforementioned «abstract concepts», and much closer to the social requirements of practicing law:

b) Professional management activities, in accordance with the ethical and administrative regulations of the organisation; the setting up of offices, businesses and companies.

c) Activities pertaining to the use of tools related to the knowledge society in which we live (an obvious reference to the use of technology in the profession).

6 This can be illustrated by the subjects of the Law degree offered By Zaragoza University, see: https://estudios.unizar.es/estudio/ver?id=132. The same is true for other European Universities, such as the University of Lisbon, Portugal, http://www.fd.ulisboa.pt /cursos/licenciatura/ plano-de-estudos/ or the University of Hannover in Germany: «Owing to the wide range of topics involved, the study of Law is a varied, exciting but also challenging programme. Contrary to all the clichés, students do not simply memorise laws. On the contrary, the study of Law involves combining professional working practices and academic work with everyday events. Did you know, for example, that by enrolling at Leibniz Universität Hannover, a relationship between you and the university is established under public law; or that an entire contract of carriage is concluded simply by getting on a train? - Those who study Law learn to develop an understanding of legal processes and problems, and how to resolve them. To this end, in addition to exploring the three areas of law - Civil Law, Criminal Law and Public Law - they also deal with the legal foundations of legal methodology and legal doctrine as well as areas related to economics and social sciences. - Simulated court proceedings, referred to as moot courts, and lawyer-related additional qualifications enable students at Hannover to gain their first practical experience for their later career whilst at university. In addition, the Faculty of Law offers its students a wide range of e-learning content, i.e. interactive courses that can be taken at home. A free examination review course is also offered» See: https://www.unihannover.de/en/studium/studienangebot/info/ studiengang/detail/law/. 
d) Activities related to communication, aimed at achieving and maintaining dialogue and consensus, making use of the advantages of interdisciplinary teamwork. (Once again, the competences have little to do with legal dogma; they are concerned with cultural plurality as the only way to maintain dialogue and consensus.7)

e) Activities oriented to putting into practice the principles of justice and the safeguarding of human rights within the Rule of Law, as specified in the following descriptive texts taken from Article 10 of the Regulation:

- «To avoid situations of damage, risk or conflict in relation to the interests entrusted to the lawyer or in the exercising of their profession before the courts or public authorities and in the function of giving guidance and advice.»

- «To know the different techniques of reconciliation of interests...»

- «To know and be able to apply professional responsibilities and codes of ethics... »

- «To know and evaluate the different responsibilities linked to the exercising of professional activity, including the basic functioning of the system of legal aid and the promotion of the social responsibility of the lawyer.»

- «To identify conflicts of interest and to understand techniques for their resolution; to establish the reach of professional secrecy and confidentiality and to maintain independence of judgement.»

- «To develop skills and abilities for the election of the correct strategy for the defence of the rights of the client... »

- «To develop skills that allow the lawyer to improve efficacy at work and foster the global functioning of the team or institution where they practice...»

- «...to extract judicial consequences and arguments, with due attention paid to the context and the party concerned, where necessary, in agreement with the mechanisms relevant to each procedural context...»

- «To develop interpersonal skills and competences that facilitate the exercising of the profession of the lawyer in their relations with...»

These competences are related to the general principles of the Law, justice and values etc. Nowadays, they are specified in the Declarations of Human Rights and incorpo-

7 On the ancient and recent history, complexity and relevance of argumentation theory, see: Breton, P., Gauthier, G., Histoire des Théories de l'argumentation, 2011, Paris, 122 pp. 
rated into the statues of many state, international and non-governmental organisations.

As might be expected, the list of skills and competences is not uniformly adopted around the world; this depends on the traditions and the idiosyncrasies of legal training and education of each country ${ }^{8}$.

\section{THE LIMITATIONS OF THE DISCUSSION ON «LEGAL INFORMATICS»}

This section does not deal with the history of Legal Informatics ${ }^{9}$; it is enough to comment that the term has been common parlance for many years and there are innumerable bibliographical references, in a variety of languages, such as «informática jurídica», «informatique juridique», «Rechtsinformatik»10 etc. New terminology tends to appear as a response to a need; in this case, it was the need for a theory capable of offering solutions for the regulation of the Law, aimed at consideration of the effects of the introduction of computer programs as auxiliary instruments to human activities.

It is worth noting that (as evidenced by numerous publications since its appearance in the second half of the $20^{\text {th }}$ century) the most significant justification for its use was that Legal Informatics should be considered as a new academic objective, even as a new science, in the study of the law. In general, the aim of the aforementioned publications was to provide curricular content for a new subject in the Law degree, in the same way that had occurred in the past with «dogmatic» materials such as Civil or Criminal Law ${ }^{11}$.

8 The International Forum on Teaching Legal Ethics and Professionalism website http://www.teachinglegalethics.org/ - gives a number of examples of the international expansion of Civil and Common Law.

9 For the history and positions of international authors on the study of this phenomena, see: Paliwala, A., (ed.) A History of Legal Informatics, 2010, Zaragoza, 287 pp.

10 For bibliographical references, ibid: pp. 255-285.

11 The manuals aimed to satisfy the myths of reason (used to order scientific knowledge since the Renaissance) and technology, the myth that became more dominant in the $20^{\text {th }}$ and $21^{\text {st }}$ centuries. On myths (deity, reason, the state, the market and technology) and their defective guide to knowledge and practice, especially in the legal arena, see, GRANT, D., BENNET MosSES, 
This aspiration seems to have become a reality when one considers the innumerable text books, manuals, scientific journals, papers and articles that are dedicated to legal informatics ${ }^{12}$. However, it has not really been consolidated as an independent subject in university study plans, especially as an obligatory course; there are some optional courses on offer, but as a specialisation, and it does not have the level of acceptance of the traditional legal dogmatic denominations.

So what is the reason for this? The answer to this question is not so much in the need to construct a theory of «Legal Informatics» or another «science of legal dogma», but in what is implicit in the reality of: 1 ) the need to regulate a Law aimed at the consideration of the effects of the introduction of computer programs on human activities; and, 2) the characterisation of the professional competences necessary for undertaking the interdisciplinary activities that can be defined as «legal informatics».

The first point will be explained with reference to an experience developed between 2010 and $2014^{13}$ with the objective of drawing up judicial proposals for the design and technical construction of «Smart Cities». The second point is illustrated through the contemplation of the first steps that have taken place for a specific service that can be seen as a model for the utilisation of «open data».

L., Technology and the Trajectory of Myth, 2017, Chettenham, 257 pages, with special interest for its clarification of the issues, pages 1 to 31 .

See, for example, the works published in: SPRINGER, Law, Governance and Technology Series, 41 volumes, http://www.springer.com/series/8808?detailsPage=titles; Prensas Universitarias, Zaragoza, Legal Framework for the Information Society Series (LEFIS SERIES), 17 volumes, http://puz.unizar.es/colecciones/57/40-LEFIS+Series.html; the International Review of Law, Computers \& Technology, 32 volumes, https://www.tandfonline.com/toc /cirl20/current; the European Journal of Law and Technology, 8 volumes, http://ejlt.org/index; and, the Revista Democracia Digital e Governo Eletrônico, 8 volumes, http://buscalegis.ufsc.br/revistas/ index.php/observatoriodoegov/index.

13 The project Ciudad 2020 - Hacia un nuevo modelo de ciudad inteligente sostenible aimed to explore issues relating to energy efficiency, the Internet of the future, the Internet of things, human behaviour, environmental sustainability, and mobility and transport, for the design of a smart, sustainable and efficient city of the future; see, https://www.indracompany.com/es/ indra/ciudad-2020-modelo-ciudad-inteligente-sostenible. 


\section{Smart Cities ${ }^{14}$}

After gaining sufficient knowledge of the services and technical infrastructures required for the functioning of smart cities, the next step is to ensure that these cities respect the constitutional rights of the citizen and all the regulations that comprise the legal system, as pertaining to the use of information and communication technologies in daily life. This implies that when services for smart cities are designed, the elements of the judicial system must be taken into account and lawyers must have sufficient skills and competences, as noted above, to carry out their work. This is a necessary requisite when designing the smart city as the provision of services will involve social changes that affect the rights of the suppliers as much as the holders of the rights to the information (citizens) which is used to offer the said services ${ }^{15}$.

An example might be the information collected by sensors on changes in the natural environment; its use has to be approved by the suppliers of the equipment (as they own the sensors) and by those that carry out the analysis and interpretation of the data that is collected. These two parties must also assume responsibility for the quality of the information and the consequences of unforeseeable effects caused by the programs that process the data. In other words, both technical and legal professionals must participate in the design and development of the services of the smart city.

Information that refers to day-to-day activities requires the personal data of the citizens to be given by voluntary consent. This personal information is preferably transformed to an anonymous format in order to preserve the rights of the citizen to privacy, as recognised by the Constitution and mandated by the regulations of the judicial

14 This subsection is a summary of: Galindo AYUDA, F., «Ciudades Inteligentes y Derechos del Ciudadano», published in: LuCas Martín. F.J, Vidal Gil, E.J., Fernández Ruiz-Gálvez, E., Bellver Capella, V., (coords.) Pensar el Tiempo Presente, 2018, Valencia, vol. 1, pp. 641-662.

15 The technological platform of Ciudad 2020 could supply services that are currently offered by, for example, travel agencies; these services would be offered via computer programs, which would be the property of the companies that supply them, facilitating, bookings of train tickets, flights, accommodation, car rental etc. These programs or services produce a specific connection between the citizen, the clients and the suppliers. This example, that is, of course, a reality, has transformed the functioning of travel agencies and is a small indication of the services that may be offered in the smart cities of the future. 
system. In this way, all kinds of information on the individual behaviour of the users can be processed and made available for those that have generated it, or other users/citizens who acquire it. Responsibility is limited to those companies that create or offer the services.

It is impossible to ignore the social transcendence of the services/applications that are being designed and implemented with the ultimate objective of the creation of smart cities. This concerns the transformation of the supply of services from the existing model for companies and organisations towards automated, data-based provision that was previously undertaken by human beings ${ }^{16}$.

The issue that must be addressed is how can these automated programs and services for the smart city be designed in a way that guarantees the rights and responsibilities (under the regulations of democratic judicial systems) of those that participate in their design, supply, acquisition and use?

The response revolves around three key elements:

1. The construction of data banks and the design of the programs.

2. Communication between the users and the data banks.

3. Regulations for the development of use of the programs/services.

Some of the characteristics of the third element (relative to legal regulation or judicial competences) will be detailed later. The first two elements, on the other hand, involve technology and belong to the field of computer science and engineering.

A discussion of the legal regulation of the systems/programs of smart cities runs up against the paradox of the unknown as there is no legal regulation on Smart Cities beyond those rules that condition research and development on their creation ${ }^{17}$, or

16 We are already witnessing the generalised introduction of robots in areas far beyond the military and automobile sector. For some of the judicial consequences, see, PAGALLLO, U. The Laws of Robots. Crimes, Contracts, and Torts, 2013, Dordrecht, pp. 183-192.

17 In Spain there is a technical committee (AEN/CTN 178 - Smart Cities) that oversees the development of industrial standards for Smart Cities, see, https://www.aenor.com/conocenos/ sala-de-informacion-aenor/Novedad?c $=49224$. There is also an ISO Committee, ISO/TC 268, dedicated to the sustainable development of communities: http://www.iso.org/iso/ iso_technical_committee?commid=656906. 
agreements made between administrative bodies, mainly local and regional councils, that have authorised projects on smart city designs, based on their generic obligation to support $\mathrm{R}+\mathrm{D}+\mathrm{i}$ activities and stimulate employment ${ }^{18}$.

It is difficult to judicially advance in line with positivist theories of the Law: theories that are limited to an exegesis of the Law. For these theories and the dogmatic science of the law, if there are no laws, the jurist cannot make judicial considerations; to do so would be to make policies, and this is the responsibility of the legislators that make the laws. In contrast, we have other judicial theories, such as communicative theory, which are concerned with the study of activities and their accommodation to the regulations, norms and values of contemporary democratic societies. These theories are not limited in the same way ${ }^{19}$ as they contemplate rules governing the design and implementation of technological services and programs due to the social function of the services and their legal/evaluative requisites, even in a limited environment such as the field of $\mathrm{R}+\mathrm{D}+\mathrm{i}$. It should also be said that the legal perspective has been of fundamental importance since the appearance of the sensors, programs and other artefacts, as they would not be able to be used in the future due to the evident illegality of those who design and used them if the systems generate defective services ${ }^{20}$.

The establishment of electronic commerce and electronic government required the establishment of legal regulations that allowed the functioning of the programs/systems in line with the principles of the legal order with the aim of overcoming the limitations that were found in the use of the new technologies. To this we

18 This is the case with the «Spanish Network of Smart Cities»: http://www. redciudadesinteligentes.es. Article 3 of their statues establishes the objective of the network as «... the generation of a dynamic between cities with the aim of making available a «Spanish network of smart cities» which will foster the automatic and efficient management of urban infrastructures and services, reducing public expenditure and improving the quality of services in order to attract economic activity and generate progress.».

19 See Galindo, F., «The Communicative Concept of Law» in Journal of Legal Pluralism and Unofficial Law, Vol. 41, 1998, pp. 111-129. Other positions establish the connection between judicial aspects and governance as another manner to promote the interdisciplinary study of the Law, see, Douglas-ScotT, S., Law after Modernity, 2013, Oxford, pp. 382-396.

20 This was the case with Facebook and applications designed by Cambridge Analytics and their abuse of personal information; see news article from the $1^{\text {st }}$ of March 2018 at: http://www.bbc.com/mundo/noticias-43226416. 
must add the evident consideration that the regulations on the design of smart cities are also dependent on regulations on the functioning of ICTs in society that have been developed and implemented over many years (since the 196os): protection of personal data, security measures, electronic signature, electronic access to public services, protection of intellectual and industrial property; and, the general measures of the legal system for the protection and attribution of responsibility.

In short, the suppliers of smart services must be clear on their responsibilities regarding the use of their products and this should be written in to the contracts that are agreed with those who provide the data and those who use the services ${ }^{21}$. In any case, there is no doubt about the interdisciplinary nature of these activities; they involve technicians and jurists: qualified, competent professionals from both these fields should participate.

\section{Open Data}

Another example of interdisciplinary demands is in the use of public and private «open data» that is available on the Internet. This is the next step in the development of the evolution of the technology and the regulations that already facilitate access to data and attempt to guarantee the transparency of the activities of public institutions ${ }^{22}$.

This data is legally published on the Internet by companies, authorities or institutions that have satisfied regulations on data protection rights. Jurists are required for evaluating the legality of the information that is collected and stored; this allows it to be utilised in technological applications by those who acquire $\mathrm{it}^{23}$.

It should be underlined that the development of these applications, as is the case with smart cites, is only possible with the intervention of jurists and technicians that un-

21 On the importance of this type of contract, see: OssowskI, S., Agreement Technologies, Springer, 2013, Dordrecht, 648 pp .

22 See, MenR, H., Artificial Intelligence for Citizen Services and Government, Harvard Ash Center Technology \& Democracy Fellow, August 2017 - https://ash.harvard.edu/files/ash/files/ artificial_intelligence_for_citizen_services.pdf.

23 On «big data» and its legal and social implications, see, HoEREN. T., KolanY-RAISER, B., (eds.), Big Data in Context. Legal, Social and Technological Insights, 2018, Cham, 120 pp. 
derstand how to model the information that is used for their construction. This is another example of the necessity of the interdisciplinary work of legal informatics ${ }^{24}$ and the justification of interdisciplinary professional activities.

\section{A JUDICIAL REFLECTION CRITICAL OF DOGMA}

The starting point for the consideration of legal education and training must focus on the concepts of the study of the Law from the times of the Renaissance, the moment when Europe accepted the idea that the object of the knowledge of reality was to be found in reality itself: of nature, that which is known and ordered in accordance with the categories and methods of reason. In other words, science and its procedures or methodologies: induction and deduction. Induction in the case of empirical knowledge of reality (Bacon) which is different to the «human»: nature ${ }^{25}$. Deduction, in the case of the knowledge of the activities of man (Descartes) ${ }^{26}$, because this is characterised, as Kant argued, by liberty ${ }^{27}$ which allows for rational constructions that, like the Law, permit coexistence and the exercising of liberty and freedom of others.

So, as much in natural science as in human activities, steps were taken to establish a knowledge of reality that was very different from the sources of reality that belonged to the Middle Ages (revelatory texts, especially the Bible). This satisfied the criteria of the expanded knowledge of the epoch, and, in the case of the Law, helped end the re-

24 This is the methodology followed by the Zaragoza University Grupo de Investigación sobre Protección de datos, Documentación y Multiculturalismo de la Universidad de Zaragoza, in their preparation of an access program for the Camino de Santiago that uses open data. See, http://lefis.unizar.es/prot-dat-doc-mul/.

25 A significant section of his main work - BACON, F., La Gran Restauración (Novum Organum), 2011, Madrid, pp. 399-419: Description of a Natural and Experimental History, such as may serve for the Foundation of a New Philosophy.

26 «En lo que toca a la razón o al sentido, siendo, como es, la única cosa que nos hace hombres y nos distingue de los animales, quiero creer que está entera en cada uno de nosotros y seguimos en eso la común opinión de los filósofos», DESCARTES, R., Discurso del método y Meditaciones metafísicas, 2005, Madrid, p. 69.

27 «...to see what I have to do in order that my volition be morally good ... I ask myself only: can you also will that your maxim become a universal law?», KANT, I., Fundamentación de la metafísica de las costumbres, 1932, Madrid, 1932, p. 37. 
ligious wars that had kept (in the 16th century) the governors of that period in power. The foundation for the origin of their power, and, the Law that they established, became based on rationality and reason, instead of on a conception of religion (catholic or protestant) that generated conflict.

Reason as the basis for power did not become a reality until the end of the $18^{\text {th }}$ century and the French revolution. This was a revolution based on an assault of power, the overthrow of the monarchy and the theory of the general will for the establishment of political power with its three, counter-balancing, elements: legislative, executive and judicial. Power was located in the legislative assembly in which sat the representatives of the nation who transformed the will, opinions and beliefs of the people into laws ${ }^{28}$; this was also the case with the constituent Assembly whose members were able to create the higher regulation of the Constitution. In fact, this was what happened in France, the Assembly created the Constitution that was the foundation of the power of the general will and expression of the organisation of political power through the mechanism of the separation of powers and the Codes, especially the Civil Code that was created by the representatives of the general will and understood as the equivalent of reason. The Code was to be considered as the sole source of the Law that regulated the daily life of individuals and it was to be interpreted and applied by jurists in specific cases ${ }^{29}$.

The objective of the protagonists and leaders of the French Revolution to spread their «achievements» to the rest of Europe was not, initially, successful as they were sup-

Preamble to the 1789 Declaration of the Rights of Man and of the Citizen, Especially: «The representatives of the French people, constituted into a National Assembly, considering that ignorance, forgetfulness or contempt of the rights of man are the sole causes of public misfortunes and of the corruption of governments, are resolved to expose, in a solemn declaration, the natural, inalienable and sacred rights of man, so that that declaration, constantly present to all members of the social body, points out to them without cease their rights and their duties; so that the acts of the legislative power and those of the executive power, being at every instant able to be compared with the goal of any political institution, are very respectful of it; so that the complaints of the citizens, founded from now on simple and incontestable principles, turn always to the maintenance of the Constitution and to the happiness of all.»: the description of these rights continues in article 17: http://www.conseil-constitutionnel.fr/conseilconstitutionnel/francais/la-constitution/les-constitutions-de-la-france/constitution-de-1791. 5082.html.-.

https://www.legifrance.gouv.fr/telecharger_pdf.do?cidTexte=LEGITEXT000006070721. 
pressed by Napoleon Bonaparte. Nevertheless, the rationalistic spirit had taken root and rationalism came to be seen as a requirement for the organisation and government of the growing liberal industrial society; a society that outlawed workers» associations and incentivised the market, freeing property from the «dead hands» of the Ancien Régime by expropriation and disentailment. This new society would dominate Europe throughout the 19th century.

Judicial rationality spread through the functioning of traditional political regimes, not revolution. The monarchies that emanated from the Ancien Régime modified their judicial systems in accordance with the principles of the market, and in a manner that respected tradition.

The jurist who was best able to reconcile tradition and modernity was the Prussian, F.K. Savigny, who combined current and existing Roman law which was applied in the tribunals and to the liberal reforms. Savigny re-established classic Roman law, incorporating legal entities such as autonomy of will, subjective rights juridical relationships and duress. ${ }^{30}$ These were rights that were necessary for the establishment of liberal society within the framework of political regimes whose justification for existence was, at the end of the day, (as in Prussia) still based on the idea that the monarch was the representative of God on earth.

The theories of Savigny were completed during the 19th century by the founders of pandecticism and conceptual jurisprudence: Puchta ${ }^{31}$, Jhering ${ }^{32}$ and Windscheid ${ }^{33}$. These scholars reviewed the history of Roman law and introduced basic juridical concepts that would form part of the German Civil Code, the drafting of which began in 1881. The Code would come into full effect on the ist of January, 190o. Times had

SAVIGNY F.K., System des heutigen Römischen Rechts, 1840, Berlin, Vol. 1 cap.2, paragraphs 4 to 16.

31 PuchtA, G.F., Lehrbuch der Pandekten, 1838, Leipzig, 629 pp.

32 Roman law was studied «in order to investigate the internal movement of law, the unknown resources, underlying causes and the immaterial correlation of the compilation of judicial developments». JHERING, R.V., Geist des römischen Rechtsauf den verschiedenen Stufen seiner Entwicklung. 1968, Aalen, Vol. 1, pp.15-16.

33 WindsChEID, B., Die Lehre des römishen Rechts von der Voraussetzung, 1850, Düseldorf, $214 \mathrm{pp}$. 
changed and societies were developing in line with the appearance of factories, industries and the economic demands of the epoch.

The repercussions of these changes would not be felt in Spain until the second half of the 19th century. In the early years of that century, the teaching of law had not been affected by the movements that were taking place in society: the content of the study plan for Law - the «Plan Caballero» (named after the Marquis de Caballero) of the 12th of July $1807^{34}$ summarised and published in the Madrid Gazette under the authority of the Gobierno de la Regencia de las Españas (11/06/1813) illustrates this point: «A guide for the study of Spanish Law, divided into two parts: The first contains the five tables that comprise a compendium of Spanish Law and must be memorised by students in the fifth year of their studies, in compliance with Royal Decree of the 12th of July 1807, concerning the new plan for university studies. The second comprises the summary of the 4,040 laws under the 340 titles of the 12 books of the new Compilation, published in 1805 and a requirement for examination in the seventh and eighth year of the course» ${ }^{35}$. The plan offered nothing new; students had to memorise and study the list of laws that were currently in force, without reference to their conceptual classification.

The 1857 Law of Public Instruction ${ }^{36}$, also known as the «Moyano Law», was, however, undoubtedly conceptual; it established guidelines for all levels of education and training. Article 43 of the law stipulated the most important areas in matters of legal training: Introduction to the Institutions and History of Roman law; the Institutions of Civil Penal, Mercantile, Political and Administrative law, in Spain including the study of Provincial Codes and Jurisdictions; the Theory and Practice of Judicial Procedures; Legal Oratory; Extension of Administrative law and its various branches; Statistics; Spanish and International Common law; Comparative Legislation. Unlike the study plan of 1807 that almost exclusively dealt with laws that were currently in force, it is clear that

See: Peset, M, «La enseñanza del derecho y la legislación sobre Universidades, durante el reinado de Fernando VII (1808-1833)», in Anuario de Historia del Derecho Español, 1968, pp. 238-243.

The Madrid Gazette under the authority of the Gobierno de la Regencia de las Españas, No. 4, 11/06/1813, page 44. PDF. Reference: BOE-C-1813-705.

The Madrid Gazette, 10/09/1857. 
the emphasis on Roman law or Real Right marked the acceptance of categories of developing conceptual constructions that were affecting daily life and legal doctrine during the $19^{\text {th }}$ century.

The study plan for legal training of 1953 was uniformly utilised until relatively recent$1 \mathrm{y}^{37}$, and it focused on conceptual or dogmatic proposals: «FIRST YEAR: Natural law; the History and Institutions of Roman law; the History of law; Political law; the Reading and Practices of Classic Legal Texts (Latin and Spanish). SECOND YEAR: Political law; Canon law; Civil law (general); Penal law (general); Economic policy. THIRD YEAR: Administrative law; Civil law (obligations and contracts); International Public law; Penal law (specific); Public Finance. FOURTH YEAR: Administrative law (specific); Employment law: Civil law (real rights); Public Finance (with special attention to Fiscal law); Procedural law; Mercantile law. FIFTH YEAR: Civil law (family and inheritance); Procedural law; Mercantile law; Private International law; the Philosophy of law».

The 1953 plan further considered an exception to this dogmatic education: Article 11 states «The Faculties of Law will organise a course on Sociology with special reference to judicial questions. The course will be obligatory but students may choose to take the course in the second, third, fourth or fifth years of their studies. The Faculties will also organise Practical Accounting courses of general interest to those who wish to enter the legal profession; these courses will be optional and those students that take them will receive a specific certificate or diplomas» 38 .

This type of education conceptually articulates a clear preference for the study of laws; the codes and dogmatic doctrine that were studied and reconstructed were those that had been conceived in Europe during the 19th century. This was logical as they were created by the rationale expressed by the legislative powers. For example, the Spanish Civil Code establishes an order of priority regarding the sources of Law, the first of which is legislation; Article 1.1 states «The sources of the Spanish legal order are the laws, customs and general principles or the Law».

37 BOE - Official Spanish State Gazette 29/08/1953, p. 5187. http://www.boe.es/datos/pdfs/ BOE//1953/241/A05185-05190.pdf.

Ibid. 
As seen above, the 1953 plan for legal studies included an obligatory course in Sociology which made "...special reference to judicial questions...» However, in reality, this course was never studied or taught; the 1953 plan almost exclusively concentrated on the study of legal dogma.

But the mention of Sociology is of particular interest as it was not unrelated to events taking place in society. From the moment that the jurisprudence of concepts was expressed in the Civil Code and its application had begun (1900), the Code was criticised precisely because it made no «reference to judicial questions». Judges were obliged to resolve the cases before them by means of the law: Article 1.7 of the Spanish Civil code states that «Judges and Tribunals have an inexorable duty to resolve matters brought to their attention in compliance with the system of established sources». Similarly, Article 4 of the French Civil Code states that «The Judge that refuses to make a judgement, under the pretext of the silence, obscurity or insufficiency of the law may be persecuted as guilty of the denial of justice.»

Proposals were also being made to introduce the induction methodologies of the natural sciences into the field of Law. This was through the application of Sociology which was developing as a science of knowledge of society with special reference to human activities, which, of course, included judicial questions.

Augusto Comte argued that from the second half of the 19th century onwards, social and moral problems had to be analysed from a positivist scientific perspective. This was a methodology based on the empirical observation of phenomena which revealed and explained behaviour in terms of universal laws that could be used to the advantage of humanity. Comte suggested that only positive science, or positivism, was able to discover the laws that govern both nature and our own social history, understood as the succession and progress of specific moments in history: social states or stages of development ${ }^{39}$. In essence, positivist philosophy was examining the social, political and economic reorganisation instigated by the Industrial Revelation that was changing the nature of society. 
In the world of Law, the critique would come from Germany and the «Free Law» movement. As Kantorowicz said in 190640 »...for us, as children of the 19th century, the world is a world in constant change and development and that is our Free Law, as perishable and fragile as the stars...» The link between Law and Sociology would be defined in Austria, by Ehrlich: «There is no doubt that jurisprudence (the Science of Law) is, above all, a practical discipline: it teaches the practical application of the Law. And this is how it has existed for millennia. But that said... it can only completely fulfil this function when is offers a morphology of human society and the forces that act within it and when it investigates its nature and limits. In this way, jurisprudence is transformed into the Science of Law, into the Doctrine of Law, understood as a social phenomenon; and as such, it is a branch of Sociology. In order to avoid misunderstandings, it should be emphasised that here we are referring to Sociology strictly in the sense of Augusto Comte's understanding and to the way that Sociology has developed as a distinct science in the course of the 19th century» ${ }^{41}$.

In Spain, Sociology, as a methodology of knowledge and practice, was effectively introduced into the judicial domain through the reform of the Civil Code in accordance with Decree 1836/1974, of the 31st of May. The preface to the regulation states that «The consideration of the social reality corresponding to the time of application of the norms introduces a factor with whose, certainly very delicate employment, it is possible, to some degree, to accommodate the judicial precepts to circumstances that arise posterior to their formation.» This was the reasoning behind the new and existing Article 3 of the Civil Code. Paragraph 1 of Article 3 states that «The laws will be interpreted in the proper sense of their words, in relation to the context, the historical and legislative antecedents and the social reality of the times in which they are to be applied, taking into account the spirit and purpose of the laws themselves» ${ }^{42}$. The most significant expression here is the appellative «social reality».

40 Kantorowicz, H.U., Der Kampf um die Rechtswissenschaft von Gnaeus Flavius, 1906, Heidelberg, p.12.

41 Ehrlich, E., Soziologie und Jurisprudenz, 1906, Czernowitz, pp.19s. On the current relevance of Sociology and the Science of Law, see, for example: HAmAnN, H., Evidenzbasierte Jurisprudenz, 2014, Tübingen, $394 \mathrm{pp}$.

42 https://www.boe.es/buscar/doc.php?id=BOE-A-1974-1083. 
The moment had arrived in which the study of reality could be undertaken with the instruments provided by the discipline of Sociology. It was now time for the legal professionals to accept the responsibility of making decisions based on the characteristics of each individual case. Up to this point, there was a strict separation between Law and Ethics that was based on legal reason, articulated by the legislative as a system of concepts in the form of Codes and Laws. This system began to be progressively eroded as values played an increasingly important role in the interpretation and application of the Law.

This process was clearly expressed by Perelman in 1976: «In the present conception of the Law, less formalist and more concerned with the manner in which it is accepted by the medium which it regulates and more interested in understanding the functioning of societal legislation, it is impossible to purely and simply identify positive law with the group of laws and regulations that have been voted and promulgated in compliance with criteria that guarantee its formal validation; there may be considerable discrepancies between the letter of the texts, their interpretation and their application. When we speak of the life of the Law, we are referring to the way in which the same legal texts have been interpreted in different manners, in accordance with the epoch in question»43.

More specifically: »...after dozens of years, we are witnessing a reaction that...trusts the judge with the mission of seeking, in each individual case, an equitable and reasonable solution whilst demanding that the solution is reached within the limits of the legal system that authorises the mission itself. To achieve the synthesis between equity and the Law, the latter is allowed to be flexible, because of the growing intervention of the unwritten rules of law, represented by the general principles of law and the consideration of juridical subjects. This new conception enhances the importance of praetorian law and makes the judge the auxiliary and indispensible complement of the legislator» ${ }^{44}$

The Law and Ethics, laws and human activities, were now inextricably linked ${ }^{45}$.

44 Ibid: paragraph 71, p. 137. for example: KYRITSIS, D., Shared Authority: Courts and Legislatures in Legal Theory, 2017, Oregon, 172pp. 


\section{E. THE CURRENT FRAMEWORK OF REFLECTION AND DEBATE}

Why is theory necessary? There is always a need for explanations, approximations and hypotheses that help us to articulate reality. This is the work of philosophers and sophists; they make proposals with reference to the historic context or the location in which they reside or on issues of interest to them. They are authors who are conscious of the fact that the methods of their work belong to the time and the material of which they write.

Legal professionals need them and this will be true as long as they offer explanations relative to their professional requirements, or, to be more specific, they are able to articulate and develop the skills and competences which are the foundations for their professional qualifications.

This section deals with two specific theories of the Law that explain and promote the skills and competences of the legal professional at the same time as forming the basis of the collaborative attitude of jurists working in cases concerning legal informatics.

So it is worth revisiting the question of which theories are most suitable for presenting and examining the professional competences required of the lawyer. As in the previous section of this work, the immediate answer would appear to be the two fundamental theories that have been advanced and developed by jurists since the times of the Renaissance: Natural Law and Legal Positivism.

Natural Law emphasises the role of the jurist in contemplating the origin and naturalrational or theological legitimisation of the Law in order to justify itself as the ideal mechanism for its amplification and development. It is capable of articulating, expanding and giving coherence and consistency to legal texts to the effects of being able to resolve problems that appear in daily life.

Legal Positivism is based on the acceptance of the regulations and principles established by the contents of the Constitutions and the functioning of the Rule of Law, integrated in the principle of the separation of powers and specified in the recognition that the Law is made up of legislation approved by Parliament. The jurist focuses on the text of the laws and other regulations promulgated by the competent institutions (legislative, executive and judicial) as the sole articulating element of their activities, 
applying them in accordance with the dogma or science of the law as solutions to the problems that appear in daily-life.

This very brief explanation of the two theories shows that they are not especially useful as a means of defining and developing the skills and competences of lawyers and jurists in contemporary society, as prescribed by the Law, Decree and Regulations on the training and education of lawyers that were mentioned in the second section of this work.

So, which legal theories can support present-day lawyers in the exercising of their profession? Before answering this question, and having noted the insufficiencies of Natural Law and Legal Positivism, it is worth considering a few issues on the requirements associated with specific social necessities present in hypothetical cases that are related to the skills and competences listed in Section B. This will be followed by an examination of two theories that are more relevant and effective to the current situation: the Communicational Theory of the Law and the Discourse Theory of the Law.

\section{Necessity: some examples.}

Article $135^{46}$, of the 2011 reform of the Spanish Constitution obliges administrative institutions to function under the principles of legality and budgetary balance, thereby emphasising the importance of fiscal regulation. This means that legal professionals who work with, or in cases involving, Public Administrations must have a good understanding of the economic regulations pertaining to the principle of «budgetary stability». This type of work is referred to in one of the five main competences established by Royal Decree, mentioned in Section B of this paper: (e) - «To know and identify the requirements of service and determinants of organisation necessary for legal counselling.»

«1. All Public Administrations will act in accordance with the principle of budgetary stability. 2. The State and Autonomous Communities will not incur a structural deficit greater than that which is established, in its case, by the European Union and its Member States. An Organic Law will set the maximum structural deficit permitted by the State and the Autonomous Communities in relation to its gross national product. Local entities must present a balanced budget». The Organic Law referred to is «Organic Law 2/2012, of the 27th of April, on Budgetary Stability and Financial Sustainability». 
Both principles (legality and economic efficiency) additionally regulate judicial activity through the procedural and organisational reforms that were introduced in 2011 regarding the functioning of the reform ${ }^{47}$, accommodating it to the requirements of institutions such as the World Bank ${ }^{48}$. This is also referred to in the competences listed in Section B: e) «To develop skills that allow the lawyer to improve efficacy at work and foster the global functioning of the team or institution where they practice through access to sources of information, the knowledge of languages, the management of knowledge and use of appropriate tools and techniques.»

A further consideration linked to the aforementioned competences (Section B - c) concerns the demands of the knowledge society, its characteristics and tools. Security in contemporary society must be fully covered by the legal system, which has to be adapted, approved, interpreted and applied while recognising that there are some traditional relationships and services of an industrial or agricultural nature and others that belong to the digital age and the knowledge society. The latter (new relationships) should also be protected by legislation ${ }^{49}$. Nowadays, even the processes of the resolution of legal conflicts ${ }^{50}$ take place within a digital environment utilising the resources offered by information and communication technologies.

Law $18 / 2011$, of the $5^{\text {th }}$ of July, regulates the use of information and communication technologies in the administration of Justice. Preamble I: «Every individual has the right to obtain effective tutelage regarding their rights before the courts and tribunals. This is recognised by judicial order in Article 24.1 of the Constitution and by Article 14.1 of the International Convent on Political and Civil Rights. In order to safeguard the said rights of the citizenry the Administration of Justice must be modernised, an essential task for consolidating the Rule of Law and improving the quality of our democracy. In this context of modernisation, one of the elements of greatest relevance is, precisely, the incorporation of new technologies into our judicial offices. Its generalised and obligatory use will contribute to the improvement of the management of judicial offices, updating their functioning and increasing levels of efficiency. The new technologies will equally allow the reduction of the costs of the public service of justice, but will also suppose an improvement in the confidence of the system, and this will improve security. It will have a direct and indirect impact on the economic system; the changes will generate new perspectives in economic relations, enhancing their fluidity and security». G.M., Wodon, Q., CAREY, K., The Changing Wealth of Nations 2018 : Building a Sustainable Future, 2018, Washington, p. 33. Payment of taxes by companies, applications for subsidies, permits etc.

Civil cases are now video recorded etc. 
The regulation of new social phenomena must consider existing legislation and other, non-legislative, norms such as rules of use, codes of practice and industrial standards that allow commercial activity and the resolution of conflicts. To only consider current regulations on similar social phenomena implies curtailment of the obligation of legislation to offer solutions to new social conflicts; this is referred to in Section B e): «To know the different techniques of reconciliation of interests and to understand how to seek solutions to problems through methods that do not only rely on the jurisdictional.»

If we focus on social needs and look at the general arguments on knowledge in our society which suggest that knowledge is founded on the implication of values and emotions and is produced in the communication process between them ${ }^{51}$, this allows us to argue that in any given legal activity it is not possible to take in to account the legal texts and regulations in the abstract, but consideration must be given to their relationships and implications with the people, the society in which they live and the values that generate the social conflict which the judicial activity aims to resolve; this is referred to in competences b), c), d) and e) of Section B.

All this leads to the conclusion that neither Natural Law nor Legal Positivism, which are exclusively based on legal texts and fundaments, are theories that offer sufficient support for legal professionals in the resolution of social problems. As we have seen, contemporary social problems require more than the sole consideration of legal texts and regulations; the law must be understood in the wider sense and take into account the codes of practice, for example, regulations applied to specific services, rules of governance and technical standards.

These resources are generated by the social and technological developments themselves when situations not contemplated by laws or legislative bodies arise. These rules are usually proposed by the creators of the services in order to offer effective regulation in the case of conflicts with the users; this is coherent when there is a pact between the parties that does not contravene current legislation and this is valid under the Rule of Law.

51 Thagard, P., Hot Thought: Mechanisms and Applications of Emotional Reason, 2008, Cambridge, 301 pages. 
It is therefore clear that we require legal theories that are more precise and specific than those so far discussed (Natural Law and Legal Positivism). The theories should be based on social needs and all the skills and competences necessary to be a lawyer or jurist, and not only those that we have noted, as included in Section B a) of this work: «To understand and develop skills that make it possible to apply the specialised academic knowledge acquired in the degree to a changing reality that has to be faced by lawyers in order to avoid situations of injury, risk or conflict in relation to the interests entrusted to them or in the exercising of their professional activities before the courts or tribunals or public authorities and in the functions of legal representation.» These competences refer directly to the study of legal texts and specialised academic knowledge: dogma or the science of the Law. However, as commented earlier, the competences required for judicial life are much more wide-ranging, in addition to judicial concepts, interpretation and application of the Law, professional legal activities must also pay attention to the ethical rules, management and commercialisation activities of the knowledge society: communicative activities, guided by attainment of the values of justice or their embodiment in regulations on human rights.

It is often the case that such circumstances mean that legal theories are organised as a «lesser evil», given that conflicts are heard before judges and members of arbitration tribunals who have to hand down resolutions in accordance with norms, interests and the aim of achieving consensus/justice/security demanded by the democratic system; and this is a reference to the Communicational Theory of Law.

\section{The Communicational Theory of Law}

The examples given so far provide evidence of the need for the Communicational Theory of Law (CTL). Unlike Natural Law and Legal Positivism, CTL does not exclusively focus on regulatory texts and rules and principles that have been generally accepted. Taking as a reference the fundamental principle of the Rule of Law, CTL is concerned with the specific communicative context and this allows all elements necessary for the solution of legal problems to be incorporated.

Gregorio Robles explains the concept in this way, «My specific proposal on Law Theory is based on contemplating the latter as a system of communication between individuals whose immanent mission is to direct human action. A system of communication 
consists of a system of signs. This is the basic idea of the denominated Communicational Theory of Law»52.

Robles goes on to make a comparison with game theory, arguing that the Law is a game in that »...the following necessary elements are present («necessary» meaning here that it is not possible to play without them): the rules of the game (called as such or with another denomination), the space, the time, the subjects (players), the competences of the latter, the procedures to be followed and the powers and obligations of the players when participating in the game.»53

These specifications can be equally applied to the demands of all scientific theories as well as the requisites of Knowledge Theory.

Based on these ideas, Robles advanced his Theory of Law, as detailed in his «Fundamentos de Teoría Comunicacional del Derecho, Volume 1». In this work, he puts forward a detailed and precise communication system that offers legal solutions through the application of game theory in a manner that is much more wide-ranging than the mere study of legal texts and their underlying principles.

The volume is itself an act of communication with students of the Law. It comprises 29 chapters with 121 lessons that outline the basic elements of the theory. These elements are integrated into proposals of legal content in accordance with the texts of laws and thoughts concerning the theory or philosophy of law and legal dogma in relation to a precisely defined, hypothetical judicial problem in terms of their factual institutional characteristics. The problems are real cases or cases that could occur in real-life situations.

The elements of this theory provide an instrument of undoubted value as a means of satisfying the competences included in Section B a) of this present work: the skills required of a lawyer set down by the aforementioned Royal Decree. However, it does not cover a range of competences and activities listed in the regulations that, as we have seen, can be considered as socially necessary.

52 Robles, G., Teoría del Derecho. Fundamentos de teoría comunicacional del Derecho. Volumen I, 2012, Cizur Menor, p. 167.

53 Ibid: p. 873. 


\section{Limitations of Communicational Theory}

We now come to examine the question of whether Communicational Theory is sufficient, or other theories are necessary. As we have noted, the skills and competences of the legal professional are varied, and not only related to knowledge of legal texts. There are competences that refer to the ethics, management and commercialisation of the activities inherent in the knowledge society which are communicative in nature and guided by the attainment of legal values and their embodiment in regulations on human rights. This suggests that it is not just judicial theory that is required; legal professionals also need theories and proposals that refer to other activities. Robles's CLT focuses on signs as the object of communication, legal texts and law making institutions are important but equal attention must be paid to the characteristics and instruments of the communication and the associated activities. It is therefore possible to conclude that it is necessary to utilise other explicatory theories which can articulate knowledge and values that are different to those that are present (explicitly or implicitly) in legal texts.

This is the legal methodology that has been employed since the $19^{\text {th }}$ century and was based on theories used in the field of science in order to provide the foundations for the full range of skills and competences of legal professionals.

Is it necessary to teach jurists theories that explain their professional competences? This is an area that is covered by the curriculum of the postgraduate Masters degree in Law, it deals with interdisciplinary training which is less concerned with dogmatic and legal sciences ${ }^{54}$, and focuses on other aspects of professional practice that are included in the skills and abilities that we analysed in Section B of this work.

It is not necessary to go into any detail regarding this material55; in reality, each specialist or expert should put forward that which they believe is most pertinent to the training in competences required for exercising the profession. This present work offers a more limited proposal although, potentially, with the same effects. The proposal

54 This area of study is the basis for the undergraduate degree in Law.

55 For details see the course content of the postgraduate Masters in Law that leads to the professional qualification of court lawyer and solicitor. 
is a scarcely explicit theory of Law, based on a communicative concept and coherent with theories on instruction in competences. It is hoped that it will serve as a theoretical support to jurists that have to learn and practice all kinds of skills and competences, and not just those related to the systemised study of positive legal texts and the values included in them.

The use of a concept as a theoretical framework is a commonly employed resource in the legal arena. That is to say, the utilisation of a concept of Law as a reference for jurists as a practical guide for exercising the competences of the legal professional, overcoming the weaknesses of using a network of concepts, institutions or legal texts that express a specific content which can become outdated due to the effects of time and space.

In line with this idea, we have proposed, in a number of works, the consideration of the Law as an activity for jurists in relation to legal texts. This is a communicative concept (see the reference supra in footnote 19). Below we offer a brief definition.

Activity means recognising that the Law, embodied in written and unwritten signs (e.g. images ${ }^{56}$ ), is always enacted by legal professionals through the undertaking of actions that can be analysed or scrutinised through the use of resources that allow the social sciences to study human behaviour and not only to study legal texts.

The concept also recognises that legal professionals are always guided by an appreciation of the value of justice that is heterogeneously present, without being able to ignore, as a belief, prejudice, conviction or sentiment in the resolution of any (judicial or extrajudicial) juridical conflict.

This concept goes further than Natural Law or Legal Positivism in that its appeal to activities, texts and values allows legal education to be based on the whole range of communicational actions required for the different skills and competences of the lawyer. In this way, the future legal professional will be forewarned and prepared for any kind of legal problem, being aware of its complexity and willing to admit the necessity and relevance of the intervention and participation of other social agents in the resolution of conflicts.

For example, the video recording of a civil case. 
This is what we would say is the utilisation of the concept behind the Discourse Theory of the Law.

\section{The Discourse Theory of the Law}

This perspective is more satisfactory than those that consider that the Law is the external imperative that protects and promotes the exercising of liberty that Savigny referred to at the end of the $18^{\text {th }}$ century, in the times when the law and its applications had to be coherent with the demands of industrialisation and the principles of the free market. It is also preferable to the more recent and complex normative concepts of the law put forward by Dreier and Alexy.

At the beginning of the 1980's Dreier argued that ${ }^{57}$ : «The law is the totality of norms that belong to the Constitution of an organised normative state or quasi-state system, once the system of norms is socially real, in general and in its totality, and essentially satisfies the ethical justification or general justification, and the norms are created in the development of this Constitution, once these are incorporated, in themselves, with a minimum reference to the social reality or the possibility of social reality and the ethical justification or the generalised possibility of justification.»

In 1992, Alexy was to argue ${ }^{58}$ : «The Law is a normative system, (1) called to justice, (2) consisting of the totality of norms that belong to a Constitution that is socially recognised, the norms are not absolutely unjust, and like the totality of norms that have been dictated in virtue of the Constitution, demonstrate a minimum of social reality or the possibility of social reality and are not absolutely unjust, and of (3) the principles and special normative arguments on which the procedures of judicial application are based and/or should be based in order to satisfy the demands of justice. "

In contrast, the discourse concept focuses on what is legally most relevant in our contemporary, complex society: its action in specific activities by the professionals of the Law in a manner which respects the idea of justice that is found in texts approved by

57 DreieR, R. «Der Begriff des Rechts» in Neue juristische Wochenschrift, 1980, p. 896.

58 ALEXY, R. Der Begriff und Geltung des Rechts, 1992, Freiburg, 1992, p. 201. 
the responsible organisations at the same time as other rules of practice or convictions that have not been approved by Parliament so will not be found in legal texts.

This form of action or professional juridical policy is in line with the demand that the Law must be exercised by the powers in a manner that is compatible with the principles of the Rule of Law, principles that represent the democracy, that by legal mandate, governs the actions of the public powers, that is to say, all those matters in which they are competent, as active agents in the social and political life of the knowledge society. This predicates the application of the law as carried out by recognised legal professionals in the complex judicial form; whilst paying attention to the mechanism of deliberation (a characteristic of governance), rather than the automatic application of (the liberal model) of subsumption.

It is therefore a good idea to summarise the guide to action proposed as a legal methodology for jurists by philosophers of Law. The guide is the basis for a discourse concept of the Law for age-old legal decisions and those constituted at the beginning of the $2 \mathrm{O}^{\text {th }}$ century with the development of capitalism through the industrial revolution and the reduction of the Law to norms and their implementation by legal positivism.

From that epoch, when judges began to be obliged to execute the German Civil Code in all cases, criticisms were raised about the idea that the application of Law by judges was being reduced to the subsumption of the specific case in the Law, as laid down and presumed by the liberal Codes and the legal positivist methodology. Ehrlich and the authors and judges of the Free Law Movement, made clear that the process of the application of the Law could not be reduced to subsumption once the irremediable existence of legal loopholes means that majority of judicial resolutions are the «free» creations of the judges themselves, for the purposes of not incurring the corresponding responsibility for not making decisions in cases, subjected to their decisions by legal imperative, whose suppositions and solutions do not coincide with those contemplated by the Law 59 .

Based on these ideas, from the 2oth century to the present day, there have been a series of discussions aimed at completing the process of the judicial application of the 
Law with other explanations. Some of the solutions that have been advanced are: the knowledge of conceptions and social convictions (proposed by Ehrlich through the sociological perspective of «Living Law»); the consideration that the judicial process and judicial reasoning are integrated by common issues or places that act as auxiliaries to application (Viehweg60); the establishment of auxiliary normative systems to application, developed through the use of logic and the construction of a normative pyramid that rationally amplifies the legal arena (Kelsen ${ }^{61}$ ); the study of laws in consideration of the fact that their interpretation is based on presuppositions of their content (Esser ${ }^{62}$, Engisch ${ }^{63}$ and Gadamer ${ }^{64}$ ); the study of the application of the Law in consideration of the wide-ranging nature of the content and argument ${ }^{65}$ that they produce (Perelman ${ }^{66}$, Alexy ${ }^{67}$ ); the consideration of social legitimacy (consensus) regarding laws and the full state organisation (the three powers) in democratic societies (Habermas ${ }^{68}$ ); and, the consideration that all human activities are undertaken with a knowledge of reality produced by contact that maintains the reality itself (autopoiesis) and not the mere lucubration or intellectual development of scientific proposals (Maturana69).

60 VienWeg T., Topik und Jurisprudenz, 1974, München, pp. 111-119.

61 KelSEn H., Teoría general del Estado, 1979, México, pp. 21-27.

62 ESSER J., Principio y norma en la elaboración jurisprudencial del derecho privado, 1961, Barcelona, pp. 309-339.

63 ENGiSH K., La idea de concreción en el derecho y en la ciencia jurídica actuales, 1968, Pamplona, pp. 349-394.

64 GADAMER H.G., Verdad y método: fundamentos de una hermenéutica filosófica, 1977, Salamanca, p. 360 .

65 A brief historical explanation of the content of the theories of argumentation can be found in: Breton P., Gauthier G., Histoire des théories de l'argumentation, 2011, Paris, 122 p.

66 Perelman Ch., La lógica jurídica y la nueva retórica, 1979, Madrid, pp. 176-233.

67 ALEXY, R. Begriff und Geltung des Rechts, 1992, Freiburg, pp. 201-206.

68 HABeRmas J., Faktizität und Geltung. Beiträge zur Diskurstheorie des Rechts und der demokratischen Rechtsstaats, 1993, Frankfurt, pp. 208-237.

69 MATURANA H., El árbol del conocimiento: las bases biológicas del conocimiento humano, 1988, Santiago de Chile, pp. 159-165. 


\section{F. CONCLUSION}

This work has outlined the reasons why, in discussions on the Law, it is necessary to place emphasis on the communicative context of judicial activities. The aim is to explain judicial activities and to offer more complex solutions than those that establish dogmatic, formal arguments based on legal texts. The said solutions are fully valid and rational in regard to a discourse concept of the Law that presents the Law as a legitimate activity of jurists in relation to legal texts. Without forgetting the value of the Communicational Theory of Law, whose reference for the construction of its elements is communication based on the signs that constitute legal texts, this present work proposes a discourse concept of the Law because it could provide the foundation for interdisciplinary education in skills and competences, including, for example, those competences related to the use of technologies or economic regulations that are requisite elements for the life of a jurist in contemporary society. 